\title{
Probiotics and the Gut Immune System: Indirect Regulation
}

\author{
Giorgio La Fata ${ }^{1} \cdot$ Peter Weber $^{1} \cdot$ M. Hasan Mohajeri ${ }^{1}$
}

Published online: 31 August 2017

(C) The Author(s) 2017. This article is an open access publication

\begin{abstract}
The gastrointestinal tract (GIT) represents the largest interface between the human organism and the external environment. In the lumen and upper part of the mucus layer, this organ hosts an enormous number of microorganisms whose composition affects the functions of the epithelial barrier and the gut immune system. Consequentially, the microorganisms in the GIT influence the health status of the organism. Probiotics are living microorganisms which, in specific conditions, confer a health benefit to the host. Among others, probiotics have immunomodulatory properties that usually act directly by (a) increasing the activity of macrophages or natural killer cells, (b) modulating the secretion of immunoglobulins or cytokines, or indirectly by (c) enhancing the gut epithelial barrier, (d) altering the mucus secretion, and (e) competitive exclusion of other (pathogenic) bacteria. This review focuses on specific bacteria strains with indirect immunomodulatory properties. Particularly, we describe here the mechanisms through which specific probiotics enhance the gut epithelial barrier and modulate mucus production. Moreover, we describe the antimicrobial properties of specific bacteria strains. Recent data suggest that multiple pathologies are associated with an unbalanced gut microflora (dysbiosis). Although the cause-effect relationship between pathology and gut microflora is not yet well established, consumption of specific probiotics may represent a powerful tool to re-establish gut homeostasis and promote gut health.
\end{abstract}

Giorgio La Fata

giorgio.lafata@dsm.com

1 DSM Nutritional Products Ltd., R \& D Human Nutrition and Health, P.O. Box 2676, CH-4002 Basel, Switzerland
Keywords Gastrointestinal tract · Microbiota · Probiotic · Immune system $\cdot$ Health status

\section{The Microbiota}

The human intestinal microbiota is composed of $10^{13}$ to $10^{14}$ microorganisms whose collective genome is defined as the microbiome [32, 33, 68]. Along the gastrointestinal tract (GIT), the number of the microorganisms differs enormously and it is mainly represented by bacteria belonging, in order of abundance, to three phyla: Bacteriodetes, Firmicutes, and Proteobacteria [44, 52, 72]. During evolution, the co-existence developed between human and microbiota (referred as symbiotic relationship) has endowed humans with extra-functional features playing a critical role in biological processes such as nutrient utilization, resistance against infections, maturation of the immune system, and host metabolism [4, 5, 9, 11, 16, 54].

The host-microbiota interaction starts already at birth when organisms are believed to be sterile [52, 79]. Recent finding, however, detected microbes in the amniotic fluid, placenta, as well as in meconium and umbilical cord $[38,56,73]$. The diversity of the microbiota is therefore dependent of the mother's microbiome being partially established at birth and varies further during development. Indeed, a newborn individual will be exposed to different bacteria if delivered by caesarian section or conventionally [22, 54]. Other parameters influencing the microbiota composition include the infant feeding as well as usage of antibiotics early in life [54]. Once established, the host-microbiota interactions are relatively stable during adulthood while decrease in the elderly $[8,33$, $56]$ when chronic and acute perturbations become more frequent and responsible for driving microbiota dysbiosis $[9,78]$. Dysbiosis is usually associated with pathological conditions [56] and indicates a state in which the microbiota produce 
harmful effects to the host via (1) qualitative and quantitative changes in the flora, (2) changes in the metabolic activities of the flora, and (3) changes in the flora distribution [37].

\section{Probiotics}

The importance of keeping a healthy microflora was already clear at the beginning of the twentieth century when consumption of yogurt and a specific mix of bacteria were associated to extended lifespan and prevention of disease [12, 51]. These observations have been the driver for the development of probiotics defined as "live micro-organisms which, when administered in adequate amounts, confer a health benefit on the host" [12, 64, 80].

Currently, a large variety of probiotics are available on the market and generally they are consumed to target gastrointestinal discomfort and pain as well as to improve the properties of the immune system. Unfortunately, the health benefits attributed to consumption of specific probiotics are not always fully supported by scientific evidence. It is therefore necessary to invest further in research to describe the mechanisms through which probiotic consumption may influence human health. This concept becomes even more relevant considering the increasing body of evidence associating an altered GIT flora to pathological conditions not directly connected with the GIT like rheumatoid arthritis, ankylosing spondylitis, allergic disorders, autoimmune disease, multiple sclerosis and more recently, psychiatric disorders and memory $[36,37,42,53,64,66,80]$.

\section{The Microbiota and the Immune System}

Being the largest interface between the body and the external environment $[20,28]$, it is not surprising that the GIT is tightly associated and constantly in communication with the immune system. Intestinal bacteria develop and regulate the host immune system and the immune system affects the composition of the intestinal microbiome [45]. In particular, the host immune system is responsible for ensuring a beneficial microbiota composition controlling specific bacteria overgrowth, but also reacting to pathogenic bacteria or molecules meeting with the intestinal barrier [45]. The interaction between immune system and pathogens is also regulated by microorganisms that can directly interact with pathogenic bacteria or indirectly stimulate the immune system to do the same. Gut homeostasis is therefore reached and maintained when the immune system establishes an appropriate balance between tolerance to commensal (not harmful), mutualistic (beneficial), and opportunistic (pathogenic) bacteria [56]. This balance is consolidated only when the immune system can communicate with the gut microbiota and a key player in this cross-talk process is a healthy intestinal barrier.
In this mini review, we will analyze the interaction between immune system and microbiota. Excellent recent reviews have already addressed the effect that specific bacteria have on the innate and adaptive immune response in human $[57,69,70]$. Therefore, we focus here on three mechanisms by which a selected number of bacteria interact indirectly with the host immune system. The first mechanism focuses on the effects produced by specific probiotic strains on the gut epithelial barrier, the second on mucus secretion and its modulation, and the third explores the antimicrobial properties of specific bacteria (probiotics and not). In this work, when available, the genes and pathways involved in the mechanisms of action are indicated, providing useful information to explore other probiotic properties and potential beneficial effects. To achieve this goal, we first describe briefly the gut intestinal barrier and how its constituents interact with the microbiota and the host immune system.

\section{The Intestinal Barrier and the Gut Immune System}

The intestinal barrier is a heterogeneous entity composed of an extra-cellular component: the mucus layer and a cellular compartment including the intestinal epithelium and an underlying lamina propria [20] (Fig. 1 and figure legend for details).

Both the mucus layer and the intestinal epithelium, each harboring several specialized cell types, represent a physical barrier to gut microbes. The intestinal epithelium consists of the following: enterocytes (or fluid transporting cells) responsible for absorbing molecules from the intestinal lumen, Paneth cells specialized in synthetizing and secreting antimicrobial peptides (AMPs) upon contact with enteric bacteria, and mucus-secreting Goblet cells and entero-endocrine cells $[20,44,76]$. In humans, the intestinal epithelium is renewed every three to 5 days, a fact that, per se, is immune protective as it removes infected or damaged cells [10]. Moreover, the permeability of the GIT epithelium has also immune protective activities and it is under the control of the tight junction (TJ) proteins. The expression of these proteins has been demonstrated to be regulated by specific probiotics and therefore TJs are discussed more in detail later in this text.

The lamina propria represents the interface between host and immune system in the gut and consists of dendritic cells, macrophages, and plasma cells, in addition to $\mathrm{B}$ and $\mathrm{T}$ lymphocytes.

Macrophages are strategically positioned in the subepithelial regions where antigens may cross the intestinal epithelium and are specialized in phagocytosing potentially harmful microbes as well as scavenging apoptotic cells and debris $[40,69]$. Intestinal dendritic cells phagocytose apoptotic cells, sample bacteria in the mucus, and subsequently, migrate to the lymph nodes where they activate T cells and the inflammatory response [69]. Plasma cells and T cells regulate the humoral response of the GIT via secretion of immunoglobulin (IgA) and several cytokines and inflammatory mediators [69]. 
Fig. 1 Schematic view of the intestinal barrier and main cellular players. The intestinal tract is presented on the upper right. The enlargement represents a schematic view of the intestinal barrier (mucus layer, intestinal epithelium, and bacterial ecosystems). All different cell types are reported below the enlargement. The red arrows highlight the interactions that specific bacteria strains establish with the intestinal barrier. Outlined here are the (1) modulation of the tight junction (TJ) proteins, (2) modulation of the mucus secretion, and (3) relationship established between different bacterial populations of the gut ecosystem (antimicrobial properties)

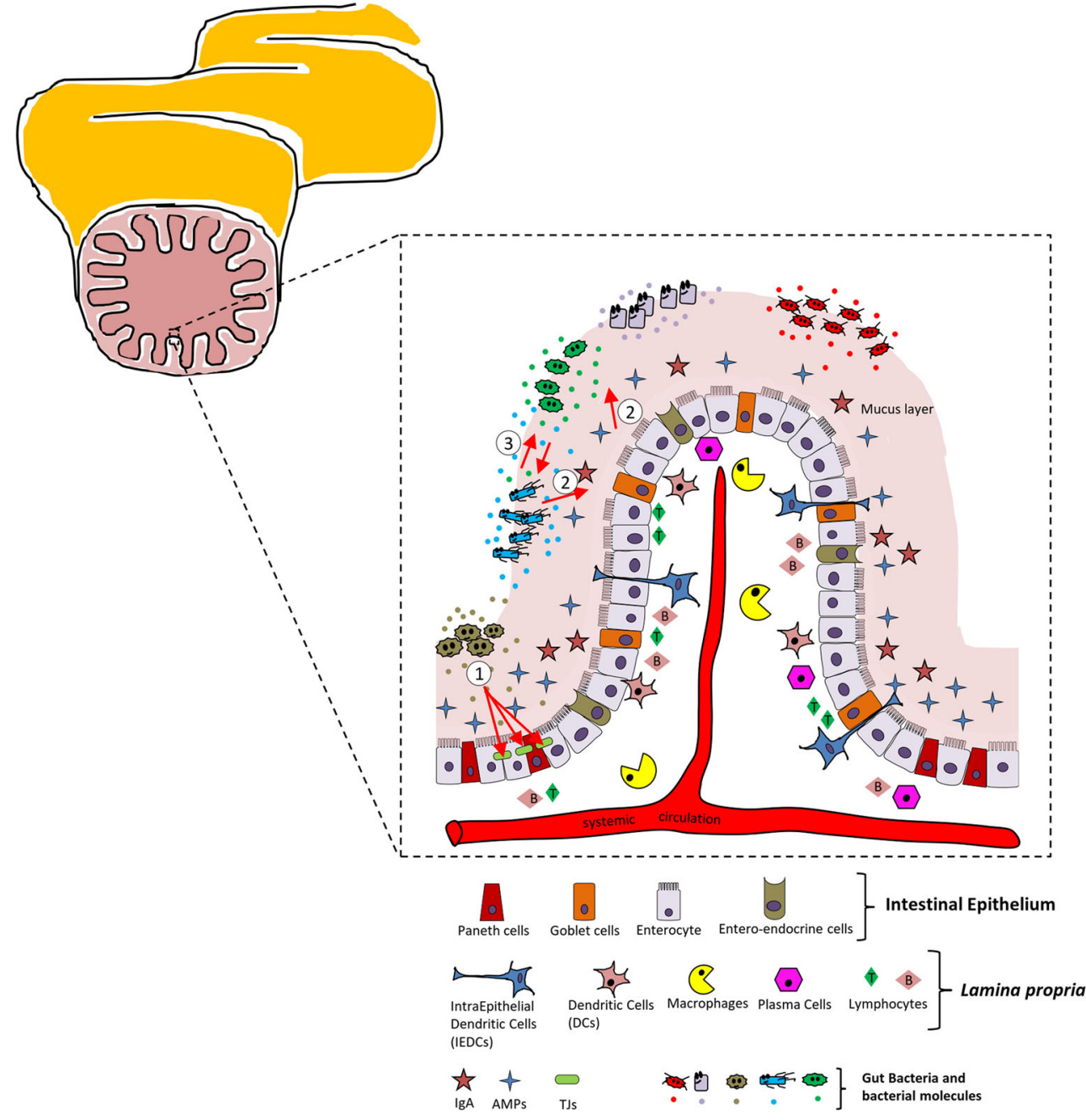

\section{Mechanisms of Action}

\section{Probiotics and the Tight Junctions in the Gut Epithelium}

One of the functions of the GIT epithelium is to establish a physical barrier between external environment and host immune system. Therefore, the functionality and integrity of this barrier are keys to support the permeability to nutrients and beneficial molecules albeit protecting the host from dangerous threats.

The integrity of the GIT epithelium is partially guaranteed by multi-protein complexes defined as TJs (Fig. 2) [29, 43, 75].

TJ's function and biology have been extensively reviewed elsewhere (for details, refers to [75] and references within). In brief, TJs are located in the apical part of the intestinal epithelial cells. They consist of transmembrane proteins that extracellularly interact with similar domain of neighboring TJs and intracellularly connect with the cellular cytoskeleton (Fig. 2).

When the expression or localization of the $\mathrm{TJ}$ proteins is altered, the functionality of this physical barrier is compromised and the leaky gut condition may develop [75].
The leaky gut is characterized by having an epithelium with increased permeability to molecules/compounds that diffuse from the lumen to the lamina propria. This condition can be measured in vitro by the trans-epithelial electrical resistance (TEER) parameter, or in vivo by the intestinal permeability test (IPT) [50]. Leaky gut is responsible for the development of multiple pathological conditions such as irritable bowel disease (IBD), irritable bowel syndrome (IBS), and celiac disease [41], all characterized by sustained inflammation and tissue damage.

Multiple compounds in the diet have already been demonstrated to regulate the expression of the TJ proteins [20] and similarly, probiotics also may regulate the expression/ localization of these proteins (Table 1).

To study the effect of Escherichia coli Nissle 1917 (EcN) in vivo, healthy germ-free mice were colonized with this probiotic and the gene expression in their intestinal epithelial cells (IECs) was analyzed [74]. Colonization of these mice with EcN resulted in an up-regulation of ZO-1 in IECs at both mRNA and protein levels [74]. Similar data were also observed when EcN was administered to murine models for 
Fig. 2 Schematic view of the gut epithelial tight junctions (TJs). Schematic and simplified view of the GIT epithelium. The dashed rectangle is enlarged below and indicates more details of the TJ structure. The proteins constituting the $\mathrm{TJ}$ are indicated. Abbreviations: F-actin (filamentous-actin), ZO (zonula occludens) 1-2-3, JAM (junctional adhesion molecule). Other proteins constituting the $\mathrm{TJ}$ and not represented in the figure include the following: myosin II (part of the cellular cytoskeleton) and tricellulin (at junction between three cells)

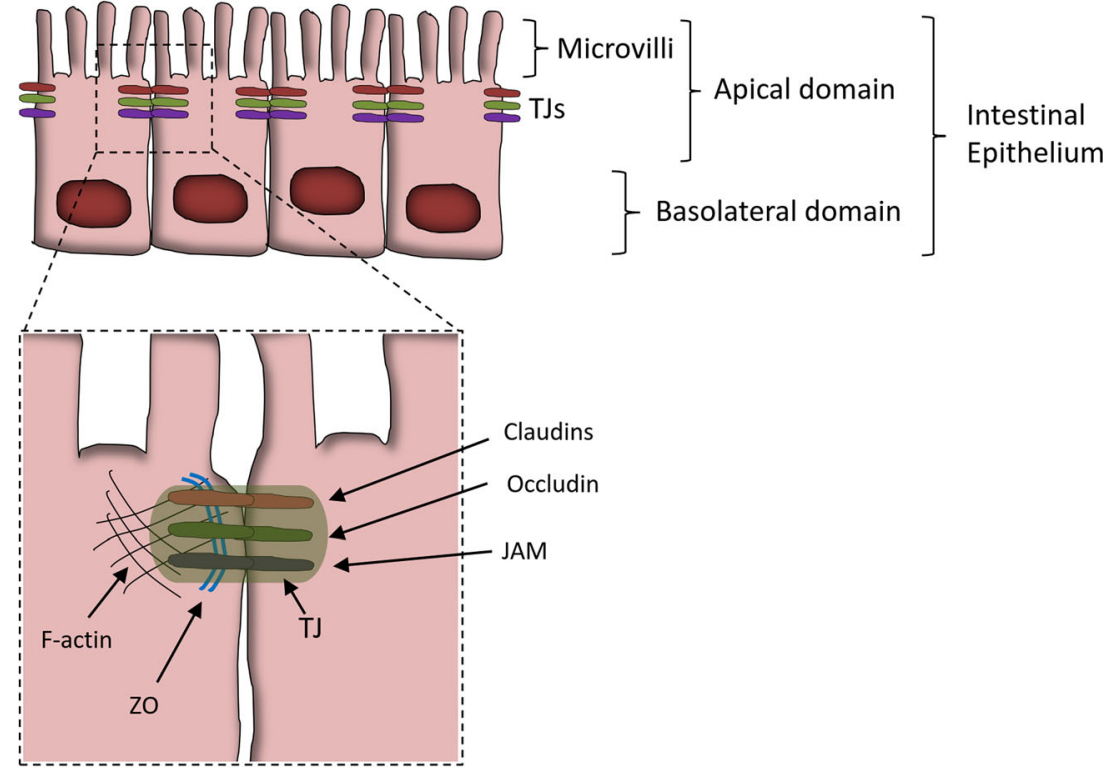

colitis suggesting that upregulation of the ZO-1 stabilizes the TJs and therefore improves the barrier function of the intestinal epithelium [74]. To investigate the molecular mechanism by which EcN contributes to the gut barrier integrity, Zyreck and collaborators used the T84 monolayer cells as in vitro model [83]. Although, in this case, they did not detect differences in ZO-1 expression, DNA microarray identified ZO-2 as key gene responsible for the probiotic effect associated to $\mathrm{EcN}$ [83]. Indeed, EcN stimulated the over-expression of the ZO-2 and redistribution (regulated partly via PKC-zeta activity) of this protein to the site where cellular contacts occur, to stabilize the TJs and maintain cell morphology [83].

The properties of the intestinal epithelium are also influenced by another probiotic. Lactobacillus rhamnosus strain GG and its protective effects against the enterohemorragic Escherichia Coli O157:H7 infections were demonstrated in vitro in MDCK-I and T84 epithelial cell monolayers [39]. Specifically, Johnson-Henry and collaborators showed that the epithelial cells treated with the probiotic prior to $E$. coli infection maintained higher levels of ZO-1 expression than those infected with the pathogen alone [39]. Similarly, the distribution of the claudin-1 protein was also retained when the cells were pretreated with the probiotic L. rhamnosus GG [39]. In this case, the stability of the epithelial barrier structure was guaranteed by ZO-1 and claudin-1, both important TJ proteins.

Similarly to L. rhamnosus GG, another probiotic strain has a protective effect against pathogen infections via regulation of TJ proteins. In the T84 epithelial cells monolayer model, Lactobacillus casei DN-114001 stabilizes the ZO-1 distribution against the enteropatogenic Escherichia coli E2348/69 [55].

Lactobacillus plantarum MB452 upregulates the gene and protein expression of ZO-1, ZO-2, occludin, and cingulin [1], as well as the expression of other genes involved in the degradation of TJ proteins such as ITCH and SNAI 1 [1] and Table 1). An increased expression of the ZO-1 and occludin genes was also observed for Lactobacillus plantarum strain WCFS1 [41] and Lactobacillus plantarum strain CGMCC No.1258 [58]. Specifically, Karczewski and collaborators administered Lactobacillus plantarum strain WCFS1 directly in the duodenum of healthy subjects by a feeding catheter. They measured the intestinal barrier parameters in the human tissue and suggested that the activation of the TLR2-dependent pathway is responsible for regulating the expression and distribution of the TJ proteins [41].

Of note, there are probiotic strains modulating TJs functions by altering the phosphorylation status of the TJ proteins only, without altering their gene expression. Pretreatment of the human intestinal epithelial cell lines HT29 and Caco-2 with Streptococcus thermophilus ATCC19258 and Lactobacillus acidophilus ATCC4356 for example, maintained the phosphorylation levels of ZO-1, occludin, and actinin when the cellular models were exposed to infections by Escherichia coli 029:NM [62].

\section{Probiotics Modulating the Properties of the Mucus Layer}

The intestinal epithelium is covered by a viscoelastic mucus layer whose main functions are to (a) build a protective barrier against the harsh luminal environment (containing digestive enzymes), (b) facilitate food passage, and (c) avoid firm adhesion of bacteria to the epithelial cells thus preventing their entry into the lamina propria $[17,20,21]$. By limiting the interaction and penetration of bacteria, a healthy mucus layer plays an important role in preventing inflammatory and infectious diseases. The mucus in the GIT is produced by Globet cells residing in the intestinal epithelium and it is mainly 
Table 1 List of probiotic strains improving the intestinal epithelium properties via TJ modulation

\begin{tabular}{|c|c|c|c|}
\hline Bacterial strain & Mechanism of action & $\begin{array}{l}\text { Increased }(\uparrow) \text { or decreased }(\downarrow) \\
\text { gene/protein expression }\end{array}$ & Reference \\
\hline Escherichia coli Nissle 1917 & $\begin{array}{l}\text { - EcN inhibits the leaky gut condition by } \\
\text { upregulation of the zonula occludens-1 } \\
\text { (ZO-1) in murine intestinal epithelial cells } \\
\text { - EcN protects against the increased mucosal } \\
\text { permeability in the dextrane sodium sulfate } \\
\text { (DSS)-induced colitis murine model } \\
\text { - T84 monolayer cells in vitro treated with EcN } \\
\text { showed increased ZO-2 expression and ZO-2 } \\
\text { redistribution (concentration at the sites of } \\
\text { cellular contacts). The redestribution of ZO-2 } \\
\text { seems to be regulated (in part) by activity of } \\
\text { the protein kinase C-zeta (PKC- } \zeta \text { ) }\end{array}$ & $\begin{array}{l}\uparrow Z \mathrm{O}-2 \\
\text { For both: gene and protein expression }\end{array}$ & {$[74,83]$} \\
\hline Lactobacillus rhamnosus GG & $\begin{array}{l}\text { In vitro pretreatment of MDCK-I and T84 } \\
\text { epithelial cell monolayers with L. rhamnosus } \\
\text { GG prevents injuries induced by enterohemorragic } \\
\text { Escherichia Coli O157:H7 infections via } \\
\text { regulation of ZO-1 (protein expression and } \\
\text { distribution) and Claudin-1 (distribution) }\end{array}$ & $\begin{array}{l}\uparrow \mathrm{ZO}-1 \\
\text { Protein expression } \\
\text { Claudin-1 } \\
\text { Protein redistribution only }\end{array}$ & {$[39]$} \\
\hline Lactobacillus casei DN-114001 & $\begin{array}{l}\text { - In vitro T84 epithelial cell monolayer treated } \\
\text { with L. casei are protected against the } \\
\text { enteropathogenic Escherichia Coli E2348/69 } \\
\text { - L. casei inhibits the redistribution of ZO-1 } \\
\text { following the infection with E. coli }\end{array}$ & $\begin{array}{l}\text { ZO- } 1 \\
\text { Protein redistribution only }\end{array}$ & {$[55]$} \\
\hline $\begin{array}{l}\text { Streptococcus thermophilus ATCC } 19258 \\
\text { Lactobacillus acidophilus ATCC } 4356\end{array}$ & $\begin{array}{l}\text { Probiotic pretreatment of the human intestinal } \\
\text { epithelial cell lines HT29/cl.19A and Caco-2 } \\
\text { exposed to Escherichia coli 029:NM maintained } \\
\text { the phosphorylation levels of ZO-1, occludin } \\
\text { and actinin }\end{array}$ & $\begin{array}{l}\text { ZO-1 } \\
\text { Occludin } \\
\text { Actinin } \\
\text { For all: phosphorylation status only }\end{array}$ & {$[62]$} \\
\hline $\begin{array}{l}\text { Bifidobacterium infantis } \\
\text { (From VSL\#3 cocktail) }\end{array}$ & $\begin{array}{l}\text { T84 cell lines treated with bioactives released } \\
\text { in the medium by } B \text {. infantis decreased } \\
\text { claudin- } 2 \text { and phospo-p38 (p-p38) expression, } \\
\text { and increased ZO-1, occludin and phospo-ERK } \\
\text { (P-ERK) expression }\end{array}$ & $\begin{array}{l}\uparrow \mathrm{ZO}-1 \\
\uparrow \text { Occludin } \\
\uparrow \text { Claudin-4 } \\
\downarrow \text { Claudin- } 2 \\
\downarrow \mathrm{P}-\mathrm{p} 38 \\
\uparrow \mathrm{P}-\mathrm{ERK} \\
\text { For all: } \\
\text { protein expression only }\end{array}$ & {$[27]$} \\
\hline Lactobacillus plantarum MB452 & $\begin{array}{l}\text { Caco-2 cells treated with } L \text {. plantarum showed } \\
\text { increased gene and protein expression of } \\
\text { occludin, ZO-1, ZO-2, cingulin, itchy homolog } \\
\text { E3 ubiquitin protein ligase (ITCH), snail } \\
\text { homolog } 1 \text { (SNAI1), and others (reference } \\
\text { for complete list) }\end{array}$ & $\begin{array}{l}\uparrow \text { Occludin } \\
\uparrow \mathrm{ZO}-1 \\
\uparrow \mathrm{ZO}-2 \\
\uparrow \mathrm{Cingulin} \\
\uparrow \mathrm{ITCH} \\
\uparrow \mathrm{SNAI} 1\end{array}$ & [1] \\
\hline Lactobacillus plantarum WCFS1 & $\begin{array}{l}\text { - Administration of } L \text {. plantarum directly in the } \\
\text { duodenum of human healthy volunteers showed } \\
\text { increased ZO- } 1 \text { and occludin proteins } \\
\text { - In in vitro Caco- } 2 \text { model } L \text {. plantarum was } \\
\text { shown to activate the Toll-like receptor } \\
\text { (TLR)-2 signaling pathway }\end{array}$ & $\begin{array}{l}\uparrow Z O-1 \\
\uparrow O c c l u d i n \\
\text { TLR-2 (activation) }\end{array}$ & {$[41]$} \\
\hline Lactobacillus plantarum CGMCC No.1258 & $\begin{array}{l}\text { L. plantarum protected the integrity of Caco- } 2 \\
\text { monolayer cells against damages by } \\
\text { entero-invasive Escherichia coli via TJ proteins } \\
\text { regulation (expression and distribution) }\end{array}$ & $\begin{array}{l}\uparrow \text { Claudin-1 } \uparrow \text { Occludin } \\
\uparrow \text { JAM-1 } \\
\uparrow \mathrm{ZO}-1\end{array}$ & {$[58]$} \\
\hline
\end{tabular}

composed by mucins. Mucins are high molecular weight glycoproteins divided in two groups: secreted mucins (coded by the MUC2, MUC5AC, MUC5B, and MUC6 genes) that are responsible for the formation of the mucus layer and transmembrane mucins (MUC1, MUC4, MUC13, MUC16) whose function is still poorly understood but likely involved in signaling pathways [17, 18, 47]. Among the different human mucin genes, MUC2 and MUC3 are the ones 
predominant in the colon [47]. Altered expression of specific mucins was associated to gastrointestinal diseases such as Crohn's disease [14] and ulcerative colitis [63] highlighting the importance of these proteins in the GIT.

Specific probiotic bacterial strains have been demonstrated to regulate mucin expression therefore influencing the properties of the mucus layer and indirectly regulate the gut immune system. A list of these probiotics is reported in Table 2 and their mechanism of action is reported more in detail below.

Lactobacillus plantarum strain $299 \mathrm{v}$ was demonstrated to inhibit the adherence of the enteropathogenic Escherichia coli to the intestinal epithelial HT-29 cell line [47]. Incubation of L. plantarum strain $299 \mathrm{v}$ with HT-29 increased the mRNA expression of the MUC2 and MUC3 genes, suggesting that this probiotic induces epithelial cells to secrete mucins that diminish enteric pathogens binding to mucosal epithelial cells [47]. These results are in agreement with previous studies performed by Bernet and collaborators who observed similar effects using Lactobacillus acidophilus strain LA1 in Caco-2 cells $[7,47]$.

The probiotic Escherichia coli Nissle 1917 was also demonstrated to alter the expression of mucin genes [35]. Specifically, incubation of HT-29 cells with $E$. coli Nissle 1917 showed an increased expression of MUC2, MUC3, MUC5AC, and MUC5A genes. This effect was stronger when a basal stimulation model was used and, with exception to MUC3, it was not observed when the only bacteria medium was used [35]. A possible explanation provided by the author regards the localization of the Toll-like receptors (TLRs) which are more abundantly present in the basal surface of the cells $[34,35]$ and represent key signaling regulators of the immune response [34].

Another probiotic able to regulate mucin expression is the Lactobacillus casei strain GG. In multiple in vitro models, it was shown that $L$. casei GG inhibited the translocation of specific pathogenic bacteria adhering to the receptors of cultured enterocytes [49] and references within) via for example, an up-regulation of the MUC2 gene expression [49].

Further evidences supporting the above-mentioned effects were also obtained by other in vitro and in vivo studies. Caballero-Franco and collaborators indeed administered a probiotic formula (VSL\#3) to rat models and observed a $60 \%$ increase in the basal mucin luminal content [15]. Subsequently they demonstrated that VSL\#3 was inducing a significant over-expression of the MUC2 gene as well as a similar, although milder, effect for MUC1 and MUC3 genes in vitro [15]. In this case, however, the specific contribution of each bacterial strain could not be determined.

\section{Bacteria with Antimicrobial Properties}

Specific bacteria strains have been described to have antimicrobial properties usually associated with secretion of peptides or molecules which enables them to compete within the complex gut ecosystems. These molecules may protect the host against infectious bacteria and favor the survival of commensal bacteria [13]. A list of bacteria with antimicrobial properties is presented in Table 3.

Lactobacillus brevis strain 925A influences the gut immune system via the production of a bacteriocin identified as brevicin 925A. Brevicin 925A was found to be effective against Listeria monocytogenes and Streptococcus mutans which cause food poisoning and dental caries [77]. Although the functional analysis of the gene coding for this compounds was not yet completed, similar bacteriocin compounds were also identified in other bacteria strain: Lactobacillus plantarum strain TMW1.25 [25, 61, 77].

Table 2 List of probiotic strains regulating the mucus layer

\begin{tabular}{|c|c|c|c|}
\hline Bacterial strain & Mechanism of action & $\begin{array}{l}\text { Increased }(\uparrow) \text { or decreased }(\downarrow) \\
\text { gene/protein expression }\end{array}$ & Reference \\
\hline Lactobacillus plantarum $299 \mathrm{v}$ & $\begin{array}{l}\text { In vitro (HT-29 cell lines), Lp299v reduces the } \\
\text { adherence of enterophatogenic Escherichia } \\
\text { coli to mucosal epithelial cells via increasing } \\
\text { the expression of mucins } 2 \text { and } 3 \text { at mRNA level }\end{array}$ & $\begin{array}{l}\uparrow M U C 2 \\
\uparrow M U C 3 \\
\text { For both: gene expression }\end{array}$ & {$[36,47]$} \\
\hline Escherichia coli Nissle 1917 & $\begin{array}{l}\text { In vitro incubation of HT- } 29 \text { cells with EcN } \\
\text { increases the expression of multiple mucin genes. } \\
\text { Milder effects were observed using inactivated } \\
\text { bacteria while stronger effects were shown for } \\
\text { polarized cells }\end{array}$ & $\begin{array}{l}\uparrow M U C 2 \\
\uparrow M U C 3 \\
\uparrow M U C 5 A C \\
\uparrow M U C 5 A \\
\text { For all: gene and protein expression }\end{array}$ & {$[35]$} \\
\hline Lactobacillus casei $\mathrm{GG}$ & $\begin{array}{l}\text { In vitro addition of LGG to Caco-2 cells reduces } \\
\text { Escherichia coli translocation via increased } \\
\text { expression of MUC2 gene expression }\end{array}$ & $\begin{array}{l}\uparrow \mathrm{MUC} 2 \\
\text { Gene and protein }\end{array}$ & [49] \\
\hline VSL\#3 (probiotic mixture) & $\begin{array}{l}\text { In vivo and in vitro experiments show that } \\
\text { exposition to VSL\#3 increases the gene } \\
\text { expression levels of MUC2 and only mildly } \\
\text { of MUC1 and MUC3 }\end{array}$ & $\begin{array}{l}\uparrow M U C 2 \\
\uparrow M U C 1 \\
\uparrow M U C 3 \\
\text { Gene expression }\end{array}$ & {$[15]$} \\
\hline
\end{tabular}


Lactobacillus fermentum strain CS57 was recently isolated from vaginal swabs and shown to produce a bacteriocin-like substance (BLS), with a wide spectrum of antimicrobial activity [67]. With a molecular weight greater than $30 \mathrm{kDa}$, the BLS was identified as probably belonging to class III bacteriocins, $\mathrm{i}$. e., heat-labile bacteriocin, whose coding genes are not yet identified. Functionally, the BLS produced by L. fermentum CS57 demonstrated a strong in vitro antimicrobial activity against Candida albicans and Streptococcus agalactiae responsible of serious infections when newborns pass through the cervical canal [67]. Similar effects were also observed earlier by combination of BLS produced by two other Lactobacilli: Lactobacillus rhamnosus L60 and Lactobacillus fermentum L23 [65]. Taken together, these data suggest that these strains may be used as potential probiotics against vaginal infections and in favor of a healthy vaginal ecosystem [65, 67].

Lactobacillus johnsonii NCC 533 was daily administered to mice infected with Salmonella typhymurium. Fecal analysis showed that the $S$. typhymurium was reduced even after the administration was stopped suggesting that LA1 is able to survive in the intestines [6]. Although the mechanism of action was not described, the authors suggested that it may involve stimulation of the immunological defenses or secretion of antimicrobial compounds [6].

Lactobacillus salivarius UCC118 is a well-characterized bacterial strain secreting a potent broad spectrum of small heatstable proteins belonging to class II bacteriocins [19]. Using infected mice models, Corr and collaborators demonstrated that oral administration of L. salivarius UCC118 was sufficient to reduce the infection of Listeria monocytogenes particularly in the liver and spleen [19]. This effect was attributed to the secretion of the bacteriocin Abp118 acting directly on the target cell and not via intermediate mechanisms [19]. Of note, in a microarray-based comparative genome hybridization analyses, Eileen and collaborators identified two novel bacteriocins in L. salivarius DPC6488 with analogies to the Abp118: salivaricin L and T [24].

Lactobacillus plantarum G1 and G3 were identified by Zavisic and collaborators [82]. The antimicrobial and bacteriocin properties of these strains were specific for multiple pathogenic bacteria such as Staphylococcus aureus, Escherichia coli, and Salmonella abony [82]. In addition to the antimicrobial properties of this strain, the authors described also high degree of viability in the gastrointestinal tract, absence of toxicity following high dose of oral administration (mice), as well as improved lipid metabolism and hepatic function (rats). Therefore, the authors propose Lactobacillus plantarum G1 (and G3) as potential novel probiotics [82].

\section{Discussion}

The physiological equilibrium established between microorganisms colonizing human intestinal tract and host is key to the health status of each individual. This equilibrium relies on complex and dynamic relationships within bacterial ecosystems and host immune system. In this manuscript, three mechanisms through which specific bacteria strains indirectly communicate with the immune system have been described. The first explores the effect that probiotic have on the gut epithelial barrier and in particular the tight junctions, the second focuses on bacteria that by communicating with the intestinal epithelium may alter the properties of the mucus layer, while the third describes the antimicrobial molecules that specific bacteria strains use to compete within the gut ecosystems.

The GIT epithelium represents a physical barrier between external environment and host immune system. The integrity of such barrier is regulated by multi-protein structures called tight junctions that are key to regulate the gut permeability to nutrients and beneficial molecules while protecting the host from threats originating within the GIT.

Multiple probiotics modulate the expression of proteins constituting the TJs and therefore were reported in this work. The studies indicated here highlighted the importance of proteins like ZO-1 and occludin whose expression is regulated by specific bacteria such as Escherichia coli Nissle 1917, Lactobacillus rhamnosus strain GG, and Lactobacillus casei strain DN114001 [39, 55, 74, 83]. In general, while most of the studies describe that probiotics modulate the expression and distribution of these and other proteins in monolayer cells in vitro, few reports describe a regulation of their phosphorylation status [27, 62]. Both expression levels and phosphorylation status of the proteins constituting the TJ structure are key mechanisms by which known probiotics or potential new ones may alter the fine equilibrium of barrier and permeability assured by the gut epithelium.

The mucus is a complex viscous proteinaceous continuous layer in the gut lumen representing the first line of defense of the host against environmental threats [21]. It is a highly hydrated gel containing glycoproteins like mucins and other important constituents such as defensins, immunoglobulins, and trophic factors [21]. Specific studies reported in this work have provided valuable information about the mechanisms by which certain bacteria strains regulate the gene expression of mucins and therefore affect the properties of the mucus layer. Such studies relied on the HT-29 and Caco-2 in vitro cellular models. Pre-incubation of HT-29 cell lines with Lactobacillus plantarum 299v resulted in a reduced adherence of the enteropathogenic bacteria Escherichia coli to the intestinal cells [47]. In this case, the effect was driven by an increased expression of the MUC2 and MUC3 genes. The mechanisms driving the over-expression of MUC2 and MUC3 were investigated further and suggested that both, a direct contact of bacterial cells with intestinal cells as well as indirect stimulation of intestinal cells via secreted molecules, were involved.

Moreover, Dykstra and collaborators showed that the interaction of this probiotic strain with the cells was responsible to enhance the cellular-driven protection via reduction of the 
Table 3 List of bacterial strains with proven antimicrobial properties

\begin{tabular}{|c|c|c|}
\hline Bacterial strain & Antimicrobial effect & Reference \\
\hline Lactobacillus brevis 925A & $\begin{array}{l}\text { Brevicin 925A has antimicrobial effect against } \\
\text { Listeria monocytogenes and Streptococcus mutans }\end{array}$ & {$[77]$} \\
\hline $\begin{array}{l}\text { Lactobacillus fermentum } \\
\text { CS57 }\end{array}$ & $\begin{array}{l}\text { In vitro antimicrobial activity against Streptococcus } \\
\text { agalactiae and Candida albicans (vaginal ecosystem) } \\
\text { Bacteriocin-like substance as antimicrobial molecule }\end{array}$ & {$[67]$} \\
\hline \multirow[t]{2}{*}{$\begin{array}{l}\text { Lactobacillus johnsonii } \\
\text { NCC } 533 \\
\text { (previously Lactobacillus } \\
\text { acidophilus LA1) }\end{array}$} & $\begin{array}{l}\text { Spent culture supernatant from LA1 contains antimicrobial } \\
\text { components that reduce the amount on Salmonella } \\
\text { typhimurium in vivo (murine models of infections) } \\
\text { and in vitro (Caco-2 model) }\end{array}$ & {$[6,44]$} \\
\hline & $\begin{array}{l}\text { Antimicrobial activity by } \mathrm{LjNCC} 533 \text { associated to lactic } \\
\text { acid and hydrogen peroxide production }\end{array}$ & {$[2]$} \\
\hline \multirow[t]{2}{*}{$\begin{array}{l}\text { Lactobacillus salivarius } \\
\text { UCC118 and DPC6488 }\end{array}$} & $\begin{array}{l}\text { Secretion of the Abp } 118 \text { bacteriocin with antimicrobial } \\
\text { activity against the Listeria monocytogenes in vivo } \\
\text { model (rodents) }\end{array}$ & {$[19,24]$} \\
\hline & $\begin{array}{l}\text { Lactobacillus salivarius DPC6488: secretion of two } \\
\text { bacteriocins (salivaricin L and T) with analogies } \\
\text { with Abp118 (see reference for details) }\end{array}$ & \\
\hline \multirow[t]{2}{*}{$\begin{array}{l}\text { Lactobacillus plantarum G1 } \\
\quad \text { and G3 }\end{array}$} & $\begin{array}{l}\text { Bacteriocin-like activity identified and characterized } \\
\text { with antimicrobial properties (for specificity see reference) }\end{array}$ & {$[82]$} \\
\hline & $\begin{array}{l}\text { Potential probiotics: high vitality in the GIT, no toxicity } \\
\text { (safety), improved lipid metabolism, and hepatic function }\end{array}$ & \\
\hline
\end{tabular}

caspase pathway activation [23]. The importance of mucins was also highlighted by other observations demonstrating a reduced number of Goblet cells in inflammatory lesions of the GIT as well as a decreased functional capacity of the mucins to bind proinflammatory molecules and to inhibit bacterial binding in the inflamed colon [30, 46, 47]. Similar data were also observed previously using Caco-2 cell line and the probiotic strain Lactobacillus acidophilus LA1 [7, 47]. These data are in agreement with the effects observed years later for Escherichia coli Nissle 1917 where, in addition to MUC2 and MUC3, other genes were also affected such as MUC5AC and MUC5A [35]. In this case, however, except for MUC3, the cultured medium did not affect the mRNA levels of the other genes.

These data not only highlight the importance of in vitro models to determine the mechanisms through which common and potential probiotics may confer health benefit to the host, but also argue that different bacterial strains have strain-specific effects that cannot be extended to other bacterial species.

The limitations associated with using in vitro studies are represented by absence of complementary effect that two or more species have influencing each other as well as absence of the bacteria-host interaction effects. In this case, a more powerful source of information can derive by in vivo models. In a recent animal study for example, Bactaeriodes thetaiotaomicron was demonstrated to increase Goblet cell differentiation and expression of mucus-related gene favoring mucus production. This effect was diminished when B. thetaiotaomicron was associated with Faecalibacterium prausnitzii. This study reveals the importance of the balance between metabolically complementary commensal bacteria in maintaining colonic epithelial homeostasis [81].
Oral administration of Lactobacillus acidophilus LA1 was shown to be protective against Salmonella typhimurium infections [6]. Of interest, a combination of in vitro and in vivo experiments suggested that the antimicrobial properties associated with LA1 were specific for $S$. typhimurium and associated with secreted molecules released by this bacterial strain [6]. Bacteriocins belong to this class of molecules and received lots of attention in recent years for their potential to be used as alternative therapies to antibiotics or in the preservative industry. For example, Bacillus thuringiensis, a bacterium isolated from human feces, produces the bacteriocin thuricin CD [60]. This bacteriocin was shown to exhibit antibacterial properties activity against $C$. difficile as well as Listeria monocytogenes without affecting other constituents of the GIT microbiota [60]. Of note, other molecules with microbicidal properties exist and they can be released by cells of the intestinal barrier directly upon stimulation by specific bacteria. This is, for example, the case of the alpha-defensin peptides released by Paneth cells in response to bacteria stimulation, contributing therefore to the innate immune response of the GIT [3]. Interestingly, the release of these molecules was regulated by bacteria only (in this case: Salmonella typhimurium, Escherichia coli and Staphylococcus aureus) and not by other microorganisms such as fungi or protozoa [3].

Other examples include the Lactobacillus plantarum $\mathrm{G} 1$ and G3 whose beneficial effects were measured by improved lipid metabolism and improved hepatic function in Wistar rats [82].

Of note, although animal models represent excellent tools to investigate the microbiome-host interactions and possible beneficial effects in vivo, they lack of the "simplicity" to establish the mechanisms of actions driving such benefits. Therefore, a combination of in vitro and in vivo models is 
essential to investigate the mechanisms of action of known probiotics as well as of novel potential probiotics.

This is the case for F. prausnitzii, an abundant anaerobic bacterium present in the human gut and belonging to the Clostridium leptum phylogenic group (Firmicutes) [59, 71]. Multiple studies have reported that $F$. prausnitzii is depleted in the mucosa of patients with inflammatory bowel disease (IBD) $[31,48,71]$ suggesting that this bacterium has a role in the IBD prevention. Indeed, F. prausnitzii was demonstrated to have anti-inflammatory properties both in vitro (in peripheral blood mononuclear cells (PBMCs) and Caco-2 cells) as well as in trinitrobenzenesulfonic acid-induced colitis animal models in vivo [71] possibly through the secretion of specific metabolites that would control the inflammatory pathway $[59,71]$.

Another bacterium with potential probiotic properties is Akkermansia muciniphyla, a mucin-degrading bacterium that resides in the mucus layer and whose presence is inversely correlated with body weight in rodents and humans [21, 26]. Also in this case, using a mouse model for type 2 diabetes, the authors describe multiple beneficial effects associated with administration of A. muciniphyla including control of inflammation, gut barrier, and gut peptide secretion mediated by endocannabinoids regulation [26].

\section{Conclusions}

In conclusion, modulation of the immune response associated with consumption of specific probiotics may occur not only via the innate and adaptive immune system, but also via (a) regulation of the intestinal epithelium permeability, (b) mucus secretion, and (c) competition within bacterial ecosystem via secretion of antimicrobial compounds. These mechanisms can be easily assessed in in vitro setting and therefore represent valid tools to study the properties of newly discovered bacteria strains.

\section{Compliance with Ethical Standards}

Conflict of Interest All authors are employee of DSM Nutritional Products.

Open Access This article is distributed under the terms of the Creative Commons Attribution 4.0 International License (http:// creativecommons.org/licenses/by/4.0/), which permits unrestricted use, distribution, and reproduction in any medium, provided you give appropriate credit to the original author(s) and the source, provide a link to the Creative Commons license, and indicate if changes were made.

\section{References}

1. Anderson RC, Cookson AL, McNabb WC, Park Z, McCann MJ, Kelly WJ, Roy NC (2010) Lactobacillus plantarum MB452 enhances the function of the intestinal barrier by increasing the expression levels of genes involved in tight junction formation. BMC Microbiol 10:316
2. Atassi F, Servin AL (2010) Individual and co-operative roles of lactic acid and hydrogen peroxide in the killing activity of enteric strain Lactobacillus johnsonii NCC933 and vaginal strain Lactobacillus gasseri KS120.1 against enteric, uropathogenic and vaginosis-associated pathogens. FEMS Microbiol Lett 304:29-38

3. Ayabe T, Satchell DP, Wilson CL, Parks WC, Selsted ME, Ouellette AJ (2000) Secretion of microbicidal alpha-defensins by intestinal Paneth cells in response to bacteria. Nat Immunol 1:113-118

4. Backhed F, Ley RE, Sonnenburg JL, Peterson DA, Gordon JI (2005) Host-bacterial mutualism in the human intestine. Science 307:1915-1920

5. Belkaid Y, Hand TW (2014) Role of the microbiota in immunity and inflammation. Cell 157:121-141

6. Bernet-Camard MF, Lievin V, Brassart D, Neeser JR, Servin AL, Hudault S (1997) The human Lactobacillus acidophilus strain LA1 secretes a nonbacteriocin antibacterial substance(s) active in vitro and in vivo. Appl Environ Microbiol 63:2747-2753

7. Bernet MF, Brassart D, Neeser JR, Servin AL (1994) Lactobacillus acidophilus LA 1 binds to cultured human intestinal cell lines and inhibits cell attachment and cell invasion by enterovirulent bacteria. Gut 35:483-489

8. Biagi E, Nylund L, Candela M, Ostan R, Bucci L, Pini E, Nikkila J, Monti D, Satokari R, Franceschi C et al (2010) Through ageing, and beyond: gut microbiota and inflammatory status in seniors and centenarians. PLoS One 5:e10667

9. Bindels LB, Delzenne NM, Cani PD, Walter J (2015) Towards a more comprehensive concept for prebiotics. Nat Rev Gastroenterol Hepatol 12:303-310

10. Bischoff SC, Barbara G, Buurman W, Ockhuizen T, Schulzke JD, Serino M, Tilg H, Watson A, Wells JM (2014) Intestinal permeability - a new target for disease prevention and therapy. BMC Gastroenterol 14:189

11. Brestoff JR, Artis D (2013) Commensal bacteria at the interface of host metabolism and the immune system. Nat Immunol 14:676-684

12. Brown AC, Valiere A (2004) Probiotics and medical nutrition therapy. Nutr Clin Care 7:56-68

13. Buffie CG, Pamer EG (2013) Microbiota-mediated colonization resistance against intestinal pathogens. Nat Rev Immunol 13:790-801

14. Buisine MP, Desreumaux P, Leteurtre E, Copin MC, Colombel JF, Porchet N, Aubert JP (2001) Mucin gene expression in intestinal epithelial cells in Crohn's disease. Gut 49:544-551

15. Caballero-Franco C, Keller K, De Simone C, Chadee K (2007) The VSL\#3 probiotic formula induces mucin gene expression and secretion in colonic epithelial cells. Am J Physiol Gastrointest Liver Physiol 292:G315-G322

16. Cani PD, Everard A (2016) Talking microbes: when gut bacteria interact with diet and host organs. Mol Nutr Food Res 60:58-66

17. Corfield AP, Myerscough N, Longman R, Sylvester P, Arul S, Pignatelli M (2000) Mucins and mucosal protection in the gastrointestinal tract: new prospects for mucins in the pathology of gastrointestinal disease. Gut 47:589-594

18. Cornick S, Tawiah A, Chadee K (2015) Roles and regulation of the mucus barrier in the gut. Tissue Barriers 3:e982426

19. Corr SC, Li Y, Riedel CU, O'Toole PW, Hill C, Gahan CG (2007) Bacteriocin production as a mechanism for the antiinfective activity of Lactobacillus salivarius UCC118. Proc Natl Acad Sci U S A 104: 7617-7621

20. De Santis S, Cavalcanti E, Mastronardi M, Jirillo E, Chieppa M (2015) Nutritional keys for intestinal barrier modulation. Front Immunol 6:612

21. Derrien M, van Passel MW, van de Bovenkamp JH, Schipper RG, de Vos WM, Dekker J (2010) Mucin-bacterial interactions in the human oral cavity and digestive tract. Gut Microbes 1:254-268

22. Dominguez-Bello MG, Costello EK, Contreras M, Magris M, Hidalgo G, Fierer N, Knight R (2010) Delivery mode shapes the 
acquisition and structure of the initial microbiota across multiple body habitats in newborns. Proc Natl Acad Sci U S A 107:11971-11975

23. Dykstra NS, Hyde L, MacKenzie A, Mack DR (2011) Lactobacillus plantarum 299v prevents caspase-dependent apoptosis in vitro. Probiotics Antimicrob Proteins 3:21-26

24. O'Shea EF, O'Connor PM, Raftis EJ, O'Toole PW, Stanton C, Cotter PD, Ross RP, Hill C (2012) Subspecies diversity in bacteriocin production by intestinal Lactobacillus salivarius strains. Gut Microbes 3:468-473

25. Ehrmann MA, Remiger A, Eijsink VG, Vogel RF (2000) A gene cluster encoding plantaricin 1.25beta and other bacteriocin-like peptides in Lactobacillus plantarum TMW1.25. Biochim Biophys Acta 1490:355-361

26. Everard A, Belzer C, Geurts L, Ouwerkerk JP, Druart C, Bindels LB, Guiot Y, Derrien M, Muccioli GG, Delzenne NM et al (2013) Cross-talk between Akkermansia muciniphila and intestinal epithelium controls diet-induced obesity. Proc Natl Acad Sci U S A 110: 9066-9071

27. Ewaschuk JB, Diaz H, Meddings L, Diederichs B, Dmytrash A, Backer J, Looijer-van Langen M, Madsen KL (2008) Secreted bioactive factors from Bifidobacterium infantis enhance epithelial cell barrier function. Am J Physiol Gastrointest Liver Physiol 295: G1025-G1034

28. Farhadi A, Banan A, Fields J, Keshavarzian A (2003) Intestinal barrier: an interface between health and disease. J Gastroenterol Hepatol 18:479-497

29. Farquhar MG, Palade GE (1963) Junctional complexes in various epithelia. J Cell Biol 17:375-412

30. Ferry DM, Butt TJ, Broom MF, Hunter J, Chadwick VS (1989) Bacterial chemotactic oligopeptides and the intestinal mucosal barrier. Gastroenterology 97:61-67

31. Frank DN, St Amand AL, Feldman RA, Boedeker EC, Harpaz N, Pace NR (2007) Molecular-phylogenetic characterization of microbial community imbalances in human inflammatory bowel diseases. Proc Natl Acad Sci U S A 104:13780-13785

32. Gill SR, Pop M, Deboy RT, Eckburg PB, Turnbaugh PJ, Samuel BS, Gordon JI, Relman DA, Fraser-Liggett CM, Nelson KE (2006) Metagenomic analysis of the human distal gut microbiome. Science 312:1355-1359

33. Giorgetti G, Brandimarte G, Fabiocchi F, Ricci S, Flamini P, Sandri G, Trotta MC, Elisei W, Penna A, Lecca PG et al (2015) Interactions between innate immunity, microbiota, and probiotics. J Immunol Res 2015:501361

34. Hafez M, Hayes K, Goldrick M, Grencis RK, Roberts IS (2010) The K5 capsule of Escherichia coli strain Nissle 1917 is important in stimulating expression of Toll-like receptor 5, CD14, MyD88, and TRIF together with the induction of interleukin-8 expression via the mitogen-activated protein kinase pathway in epithelial cells. Infect Immun 78:2153-2162

35. Hafez MM (2012) Upregulation of intestinal Mucin expression by the probiotic bacterium E. coli Nissle 1917. Probiotics Antimicrob Proteins 4:67-77

36. Hardy H, Harris J, Lyon E, Beal J, Foey AD (2013) Probiotics, prebiotics and immunomodulation of gut mucosal defences: homeostasis and immunopathology. Nutrients 5:1869-1912

37. Hawrelak JA, Myers SP (2004) The causes of intestinal dysbiosis: a review. Altern Med Rev 9:180-197

38. Jimenez E, Marin ML, Martin R, Odriozola JM, Olivares M, Xaus J, Fernandez L, Rodriguez JM (2008) Is meconium from healthy newborns actually sterile? Res Microbiol 159:187-193

39. Johnson-Henry KC, Donato KA, Shen-Tu G, Gordanpour M, Sherman PM (2008) Lactobacillus rhamnosus strain GG prevents enterohemorrhagic Escherichia coli O157:H7-induced changes in epithelial barrier function. Infect Immun 76:1340-1348

40. Kanai T, Ilyama R, Ishikura T, Uraushihara K, Totsuka T, Yamazaki M, Nakamuma T, Watanabe M (2002) Role of the innate immune system in the development of chronic colitis. J Gastroenterol 37(Suppl 14):38-42

41. Karczewski J, Troost FJ, Konings I, Dekker J, Kleerebezem M, Brummer RJ, Wells JM (2010) Regulation of human epithelial tight junction proteins by Lactobacillus plantarum in vivo and protective effects on the epithelial barrier. Am J Physiol Gastrointest Liver Physiol 298:G851-G859

42. King C, Sarvetnick N (2011) The incidence of type-1 diabetes in NOD mice is modulated by restricted flora not germ-free conditions. PLoS One 6:e17049

43. Lee SH (2015) Intestinal permeability regulation by tight junction: implication on inflammatory bowel diseases. Intest Res 13:11-18

44. Lievin-Le Moal V, Servin AL (2014) Anti-infective activities of lactobacillus strains in the human intestinal microbiota: from probiotics to gastrointestinal anti-infectious biotherapeutic agents. Clin Microbiol Rev 27:167-199

45. Llorente C, Schnabl B (2015) The gut microbiota and liver disease. Cellular and molecular gastroenterology and hepatology 1:275-284

46. Mack DR, Gaginella TS, Sherman PM (1992) Effect of colonic inflammation on mucin inhibition of Escherichia coli RDEC-1 binding in vitro. Gastroenterology 102:1199-1211

47. Mack DR, Michail S, Wei S, McDougall L, Hollingsworth MA (1999) Probiotics inhibit enteropathogenic E. Coli adherence in vitro by inducing intestinal mucin gene expression. Am J Phys 276:G941-G950

48. Martinez-Medina M, Aldeguer X, Gonzalez-Huix F, Acero D, Garcia-Gil LJ (2006) Abnormal microbiota composition in the ileocolonic mucosa of Crohn's disease patients as revealed by polymerase chain reaction-denaturing gradient gel electrophoresis. Inflamm Bowel Dis 12:1136-1145

49. Mattar AF, Teitelbaum DH, Drongowski RA, Yongyi F, Harmon CM, Coran AG (2002) Probiotics up-regulate MUC-2 mucin gene expression in a Caco-2 cell-culture model. Pediatr Surg Int 18:586-590

50. Menard S, Cerf-Bensussan N, Heyman M (2010) Multiple facets of intestinal permeability and epithelial handling of dietary antigens. Mucosal Immunol 3:247-259

51. Metchnikoff E (1908) The prolongation of life: optimistic studies. In: Chalmers Mitchell P (ed) GP Putnam's Sons: New York, London, 1908

52. Montalban-Arques A, De Schryver P, Bossier P, Gorkiewicz G, Mulero V, Gatlin DM 3rd, Galindo-Villegas J (2015) Selective manipulation of the gut microbiota improves immune status in vertebrates. Front Immunol 6:512

53. Ochoa-Reparaz J, Mielcarz DW, Wang Y, Begum-Haque S, Dasgupta S, Kasper DL, Kasper LH (2010) A polysaccharide from the human commensal Bacteroides fragilis protects against CNS demyelinating disease. Mucosal Immunol 3:487-495

54. Ottman N, Smidt H, de Vos WM, Belzer C (2012) The function of our microbiota: who is out there and what do they do? Front Cell Infect Microbiol 2:104

55. Parassol N, Freitas M, Thoreux K, Dalmasso G, Bourdet-Sicard R, Rampal P (2005) Lactobacillus casei DN-114 001 inhibits the increase in paracellular permeability of enteropathogenic Escherichia coli-infected T84 cells. Res Microbiol 156:256-262

56. Peterson CT, Sharma V, Elmen L, Peterson SN (2015) Immune homeostasis, dysbiosis and therapeutic modulation of the gut microbiota. Clin Exp Immunol 179:363-377

57. Powell N, Walker MM, Talley NJ (2017) The mucosal immune system: master regulator of bidirectional gut-brain communications. Nat Rev Gastroenterol Hepatol 14:143-159

58. Qin H, Zhang Z, Hang X, Jiang Y (2009) L plantarum prevents enteroinvasive Escherichia coli-induced tight junction proteins changes in intestinal epithelial cells BMC Microbiol 9:63

59. Qiu X, Zhang M, Yang X, Hong N, Yu C (2013) Faecalibacterium prausnitzii upregulates regulatory $\mathrm{T}$ cells and anti-inflammatory 
cytokines in treating TNBS-induced colitis. Journal of Crohn's \& colitis 7:e558-e568

60. Rea MC, Sit CS, Clayton E, O'Connor PM, Whittal RM, Zheng J, Vederas JC, Ross RP, Hill C (2010) Thuricin CD, a posttranslationally modified bacteriocin with a narrow spectrum of activity against Clostridium Difficile. Proc Natl Acad Sci U S A 107:9352-9357

61. Remiger A, Eijsink VG, Ehrmann MA, Sletten K, Nes IF, Vogel RF (1999) Purification and partial amino acid sequence of plantaricin 1.25 alpha and 1.25 beta, two bacteriocins produced by Lactobacillus plantarum TMW1.25. J Appl Microbiol 86:1053-1058

62. Resta-Lenert S, Barrett KE (2003) Live probiotics protect intestinal epithelial cells from the effects of infection with enteroinvasive Escherichia coli (EIEC). Gut 52:988-997

63. Rhodes JM (1997) Colonic mucus and ulcerative colitis. Gut 40: $807-808$

64. Rijkers GT, de Vos WM, Brummer RJ, Morelli L, Corthier G, Marteau P (2011) Health benefits and health claims of probiotics: bridging science and marketing. Br J Nutr 106:1291-1296

65. Ruiz FO, Gerbaldo G, Garcia MJ, Giordano W, Pascual L, Barberis IL (2012) Synergistic effect between two bacteriocin-like inhibitory substances produced by Lactobacilli strains with inhibitory activity for Streptococcus agalactiae. Curr Microbiol 64:349-356

66. Russell SL, Gold MJ, Willing BP, Thorson L, McNagny KM, Finlay BB (2013) Perinatal antibiotic treatment affects murine microbiota, immune responses and allergic asthma. Gut Microbes 4:158-164

67. Sabia C, Anacarso I, Bergonzini A, Gargiulo R, Sarti M, Condo C, Messi P, de Niederhausern S, Iseppi R, Bondi M (2014) Detection and partial characterization of a bacteriocin-like substance produced by lactobacillus fermentum CS57 isolated from human vaginal secretions. Anaerobe 26:41-45

68. Savage DC (1977) Microbial ecology of the gastrointestinal tract. Annu Rev Microbiol 31:107-133

69. Schenk M, Mueller C (2008) The mucosal immune system at the gastrointestinal barrier. Best Pract Res Clin Gastroenterol 22:391-409

70. Smolinska S, Groeger D, O'Mahony L (2017) Biology of the microbiome 1: interactions with the host immune response. Gastroenterol Clin N Am 46:19-35

71. Sokol H, Pigneur B, Watterlot L, Lakhdari O, Bermudez-Humaran LG, Gratadoux JJ, Blugeon S, Bridonneau C, Furet JP, Corthier G et al (2008) Faecalibacterium prausnitzii is an anti-inflammatory commensal bacterium identified by gut microbiota analysis of Crohn disease patients. Proc Natl Acad Sci U S A 105:16731-16736

72. Spor A, Koren O, Ley R (2011) Unravelling the effects of the environment and host genotype on the gut microbiome. Nat Rev Microbiol 9:279-290
73. Stout MJ, Conlon B, Landeau M, Lee I, Bower C, Zhao Q, Roehl KA, Nelson DM, Macones GA, Mysorekar IU (2013) Identification of intracellular bacteria in the basal plate of the human placenta in term and preterm gestations. Am J Obstet Gynecol 208(226):e221-e227

74. Ukena SN, Singh A, Dringenberg U, Engelhardt R, Seidler U, Hansen W, Bleich A, Bruder D, Franzke A, Rogler G et al (2007) Probiotic Escherichia coli Nissle 1917 inhibits leaky gut by enhancing mucosal integrity. PLoS One 2:e1308

75. Ulluwishewa D, Anderson RC, McNabb WC, Moughan PJ, Wells JM, Roy NC (2011) Regulation of tight junction permeability by intestinal bacteria and dietary components. J Nutr 141:769-776

76. Vaishnava S, Behrendt CL, Ismail AS, Eckmann L, Hooper LV (2008) Paneth cells directly sense gut commensals and maintain homeostasis at the intestinal host-microbial interface. Proc Natl Acad Sci U S A 105:20858-20863

77. Wada T, Noda M, Kashiwabara F, Jeon HJ, Shirakawa A, Yabu H, Matoba Y, Kumagai T, Sugiyama M (2009) Characterization of four plasmids harboured in a Lactobacillus brevis strain encoding a novel bacteriocin, brevicin 925A, and construction of a shuttle vector for lactic acid bacteria and Escherichia coli. Microbiology 155:1726-1737

78. Walker AW, Lawley TD (2013) Therapeutic modulation of intestinal dysbiosis. Pharmacol Res 69:75-86

79. Walter J, Britton RA, Roos S (2011) Host-microbial symbiosis in the vertebrate gastrointestinal tract and the Lactobacillus reuteri paradigm. Proc Natl Acad Sci U S A 108(Suppl 1):4645-4652

80. Wang H, Lee IS, Braun C, Enck P (2016) Effect of probiotics on central nervous system functions in animals and humans: a systematic review. J Neurogastroenterol Motil 22(4):589-605. https://doi. org/10.5056/jnm16018

81. Wrzosek L, Miquel S, Noordine ML, Bouet S, Joncquel ChevalierCurt M, Robert V, Philippe C, Bridonneau C, Cherbuy C, RobbeMasselot $\mathrm{C}$ et al (2013) Bacteroides thetaiotaomicron and Faecalibacterium prausnitzii influence the production of mucus glycans and the development of goblet cells in the colonic epithelium of a gnotobiotic model rodent. BMC Biol 11:61

82. Zavisic G, Petricevic S, Radulovic Z, Begovic J, Golic N, Topisirovic L, Strahinic I (2012) Probiotic features of two oral Lactobacillus isolates. Braz J Microbiol 43:418-428

83. Zyrek AA, Cichon C, Helms S, Enders C, Sonnenborn U, Schmidt MA (2007) Molecular mechanisms underlying the probiotic effects of Escherichia coli Nissle 1917 involve ZO-2 and PKCzeta redistribution resulting in tight junction and epithelial barrier repair. Cell Microbiol 9:804-816 